\title{
Ethnologies
}

\section{The Arabian Nights Reader. By Ulrich Marzolph, ed., (Detroit, Wayne State University Press, 2006. Pp v-373, table of content, introduction, notes, work cited, index, ISBN 0-8143-3259-5)}

\section{Genia Boivin}

Volume 32, numéro 1, 2010

Jouer

Play

URI : https://id.erudit.org/iderudit/045222ar

DOI : https://doi.org/10.7202/045222ar

Aller au sommaire du numéro

\section{Éditeur(s)}

Association Canadienne d'Ethnologie et de Folklore

ISSN

1481-5974 (imprimé)

1708-0401 (numérique)

Découvrir la revue

Citer ce compte rendu

Boivin, G. (2010). Compte rendu de [The Arabian Nights Reader. By Ulrich

Marzolph, ed., (Detroit, Wayne State University Press, 2006. Pp v-373, table of content, introduction, notes, work cited, index, ISBN 0-8143-3259-5)].

Ethnologies, 32(1), 223-225. https://doi.org/10.7202/045222ar d'utilisation que vous pouvez consulter en ligne. 
to the individuals at their centre. Linger sets out to characterize personal experience within anthropology's predominantly theoretical and macro treatment and to bridge the two. Ultimately though, he does this in theory but not in practice. This being said, his study is still well worth reading. Linger confronts the existing drawbacks of anthropological research and teaching in evaluating the personal experience only through theoretical representations. He wades through analytical lexicons and successfully locates suitable language for describing experience without dehumanizing the person at anthropology's centre. Finally, Linger has directed much needed attention towards the relations between macro structures and subjectivities that are innermost for building theories of the individual.

\author{
Marie Croll \\ Memorial University \\ Cormer Brook, Newfoundland EF Labrador
}

The Arablan Nights Reader. By Ulrich Marzolph, ed., (Detroit, Wayne State University Press, 2006. Pp v-373, table of content, introduction, notes, work cited, index, ISBN 0-8143-3259-5)

The work of fiction Alf Laila wa-Laila or the Arabian Nights, as known in popular culture, was introduced to the West in the XVIIIth century. The Arabian Nights Reader is part of larger series in fairy-tale studies. Ulrich Marzolph, the editor, is one of the world's foremost scholars of Near Eastern narrative culture. His "Arabian Nights Reader" provides 16 articles, from both Eastern and Western scholars, in English language, and covers a research period of about 55 years (1942-1997). It aims at introducing non-specialists to relevant scholarly ideas and problems surrounding the Nights, as many scholars like to call them. However, this book, in spite of the intentions of its editor, assumes the reader is familiar with the topic and I would suggest that some preliminary research on the Arabian Nights would be advantageous.

The first part of the book is constituted by a single article, examining the researchers' reception of the Arabian Nights from the $19^{\text {th }}$ century onward, as well as the classification of genre, origins, and foreign influences. The author, Muhsin Jassim Ali, lists and criticized some of the greatest scholarly work done about the Nights that have cast the foundations for their study. 
The second part offers a selection of four texts presenting a more historical -oriented approach. This section of the book is valuable for the field of folklore for, besides arguing of the date of production of the Nights, it examines the different perspectives of the Western world on the Orient. Furthermore, it demonstrates how one can learn about history and culture from a simple tale. Texts present systematic examinations that might be too specialized for some readers. All these articles base their argument upon old manuscripts of the Nights. It seems the field does not agree on when the original manuscripts of the Nights were dated. Nonetheless, some of these authors have focused their research on the identification of the iconic but historically false editions of the Nights. They also discuss the problems around translation, fabrication and adaptation of the text. This is the section of the book that seems less accessible for a reader without background information.

The third part of the book consists of three texts, which present an argumentation based on textual analysis and foreign influences. Gustave E. von Grunebaum proposes a study of the traces of Greek romance in the Nights through the examinations of similar structure and motifs of love and faith. The Nights has multiple roots from different cultures and its content, that might not be exclusively Oriental, is an issue for many scholars. Romance is also studied by Peter Heath, who examines this genre as one of the most important of the Arabian Nights. It is a genre that exists through the tension between fantasy and reality, this concept is embodied in the story of Shahrazad fighting for her life. Her passive fight passes through oral tradition, which is, as Tzvetan Todorov demonstrates, synonymous of survival. The characters become actions because their traits are causal rather psychological. In the Nights, any character is a potential story and romance is used to reassure and comfort the reader or listener of the tale. Thus the Nights show a double function of comforting both the king Shahriyar within the story and the reader standing outside the diegesis.

The fourth part of The Arabian Nights Reader proposes case studies based on specific tales of the Nights: The "Tale of the Three Apples" by Roger Allen, the "Tale of "Ali b. Bakkar and Shams al-Nahar" by Jamel Eddine Bencheikh, "Aladdin and the Magic Lamp" by Michael Copperson, the "Tale of the City of Brass" (Andras Hamori), the "Tale Told by the King's Steward" (Muhsin Mahdi) and "Sinbad the Sailor" (Peter D. Molan). The articles deal first with the literary techniques of storytelling, the use and manipulation of historical facts and the 
interpretation one can see in the tales. They also examine new forms of entertainment, such as film, that provoked a greater manipulation of the original source of inspiration. Literary technique such as framing, (or the story within a story) and the use of violence as a theme, enables the reader to make a moral judgment onto someone else's bad actions, like king Shahriyar's does. Shahrazad's stories are meant to create a parallel between the bad character of the tale and the king to whom she narrates the parable. The use of historical elements gives more credibility to the tale and a basis for a stronger reaction from the person who reads/hears it.

The last part of The Arabian Night Reader is constituted of one single article: Fedwa Malti-Douglas' examination of feminism in Shahrazad's protagonist. The author compares two different contemporary literary works of two feminist authors, with the original text that was written by men. Both authors focus on the conclusion of the Nights. One presents the death of the king and enables Shahrazad to become independent, thus encouraging a model of solitary woman. The second recasts the patriarchal system to the extreme, where Shahriyar becomes the universal powerful male and Shahrazad a pale and mysterious figure. It presents sexual politics as universal and unchangeable. Both present the woman character in a very different way but reach the same goal of talking for the feminine.

As mentioned before, the historical portion of the book will remain the main issue for many readers who have no background in the field. Perhaps a small paragraph from the editor, linking the texts or an explanation about the general field in the introduction would have avoided such confusion. The editor does not provide English translation of Arabic transliterations, Greek, French and other languages used in the book. The readers who do not master these languages might loose a part of the argumentation of the authors. Overall, The Arabian Nights Reader is interesting and offers a good background in the field, but is rather inaccessible to someone who wishes to learn more about the Oriental tales.

Genia Boivin

University of Alberta 